International Journal of Kurdish Studies

(ISSN:2149-2751)

2 (3), pp. $179-195$

http://www.ijoks.com

\title{
The Features and Meanings of Some Similar Kurdish Words in Khani's and Mawlawy's Poems
}

\author{
Mohammad Ahmad Saed ${ }^{I}$
}

Received: April 23, 2016

Reviewed: May 02, 2016

Accepted: July 22, 2016

\begin{abstract}
The present study entitled "The Features and Meanings of Some Similar Kurdish Words in Khani'sand Mawlawy's Poems" which is an analytical and descriptive study. The purpose behind this study is to highlight those similar words that have identical features and meanings and can be found in the texts of both poets. The first axis of the study is specified to give a brief account of both Kurmanji and Goran dialects along with a synopsis of the both poets biography. In their lives, poetshad their own influence on the Kurdish poetry and literature, on the one hand Khani affected the nationalist concept and ideology, on the other hand Mawlawy had his own effect in employing his natural imagery and his lyrical themes. The second axis of this study is devoted to tackle the reasons behind resemblance between Kurdish dialects in some grammatical cases. and referring to those words that are used by both poets with the same meaning and imagery. The number of the similar words that are found in Mawlawy's anthology and Khani'sMumwzin is approximately $30-40$ words. Those words taken from the mentioned sources are the data of analysis of this study which are used in poetical phrases and sentences. One of the findings of this study is that despite of having some sound differences between Kurdish dialects, those variations have little effect on the standardization of the Kurdish language. However, the Kurdish language with its different dialects is an authentic, genuine, old and consistent language.
\end{abstract}

Recommended citation:

Saed, M. A. (2016). The Features and Meanings of Some Similar Kurdish Words in Khani's and Mawlawy's Poems. International Journal of Kurdish Studies 2 (3), 179 - 195.

1 Professor, Department of Kurdish language, Faculty of languages, University of Sulaimani, Sulaimani, Kurdistan Region - F.R. Iraq. E-mail; Mohammed.saeed@ univsul.edu.iq 


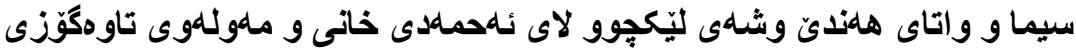

محاممهل ئلهحملة سهعيد

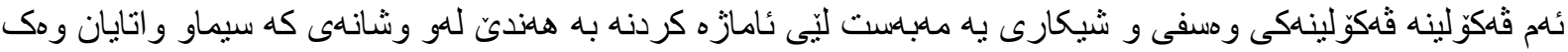

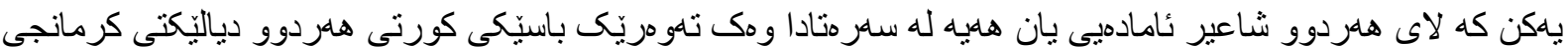

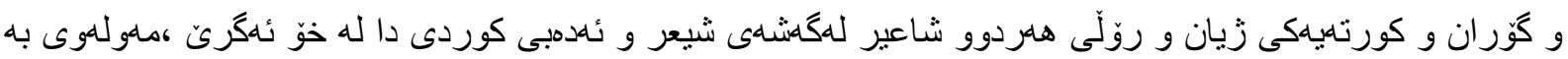

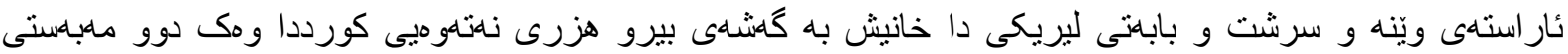

شيعرى

تهو هرى دوو هميش رووى لِّكجِو اندن نيّو ان هلردوو دياليّكت له رووى هلندى بوارى رِيّزمانى و دوّخهوه.

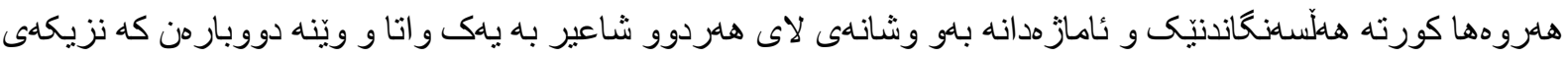

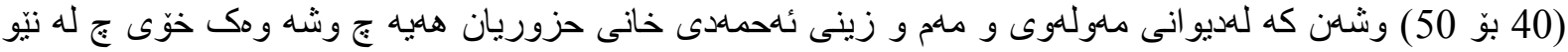

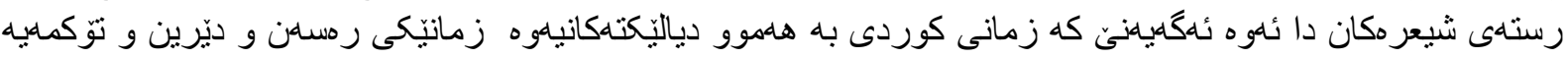

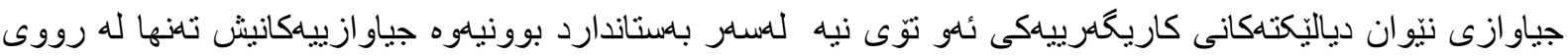

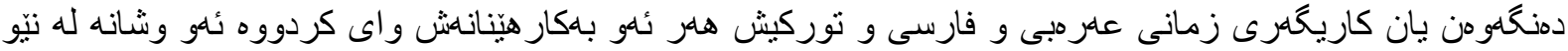

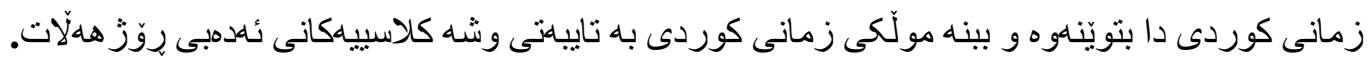

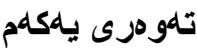

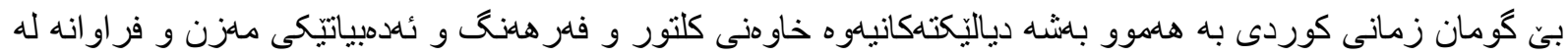

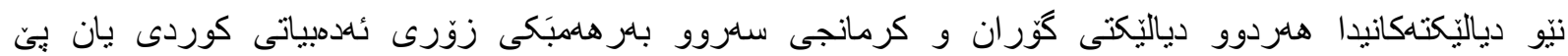

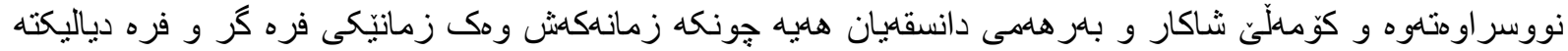

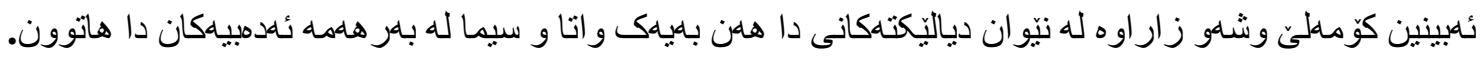

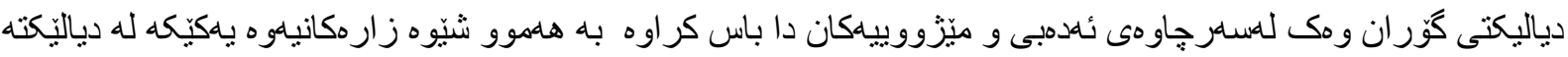

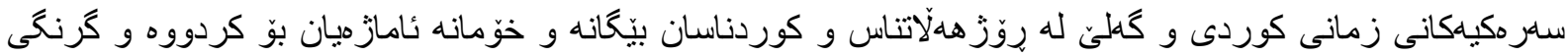

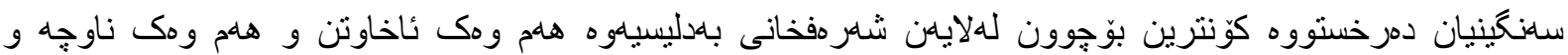

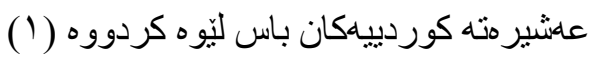

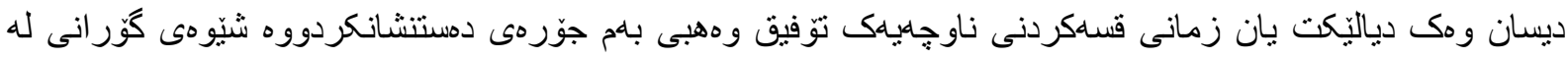

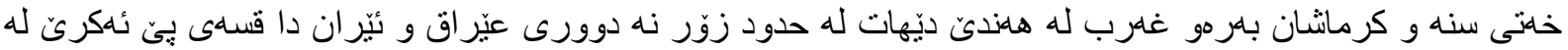

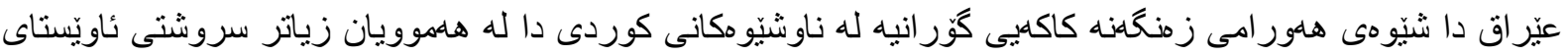

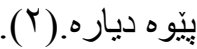

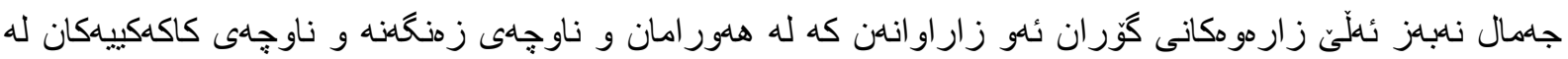

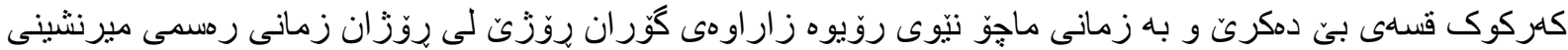

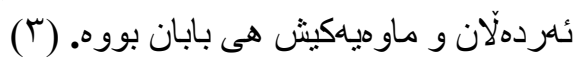




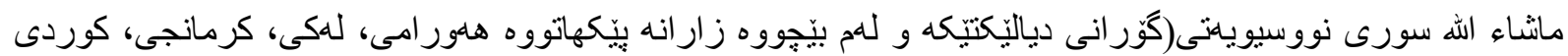

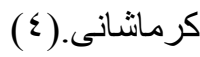

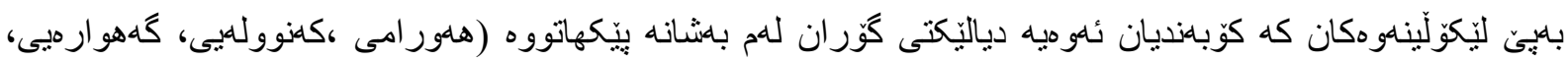

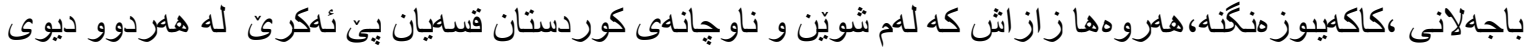

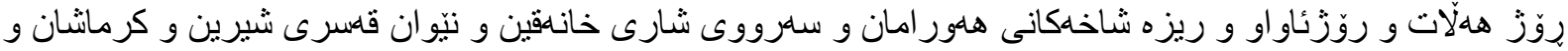

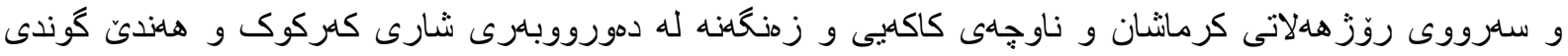

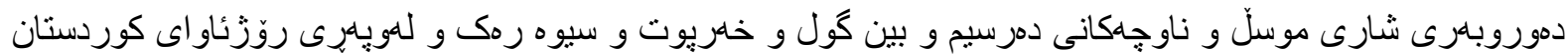

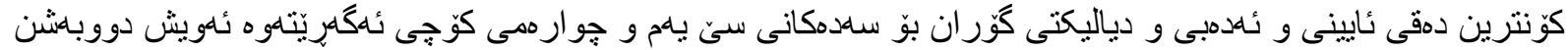

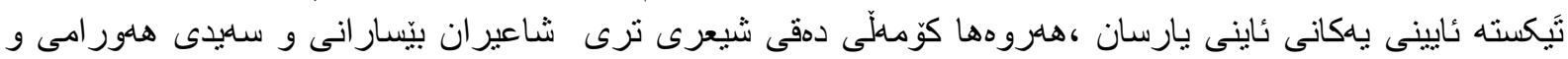

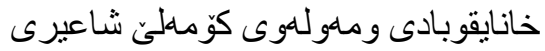

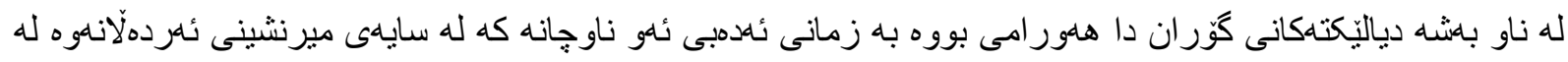

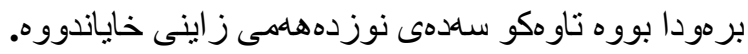

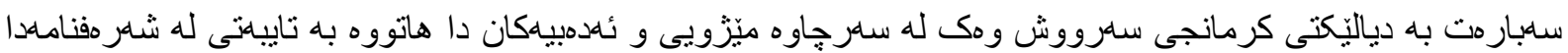

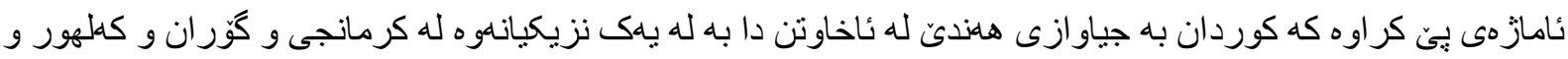

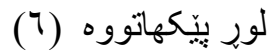

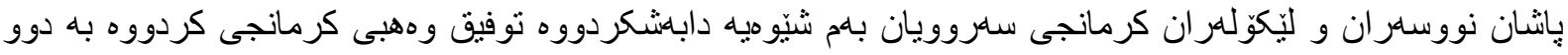

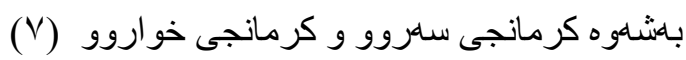

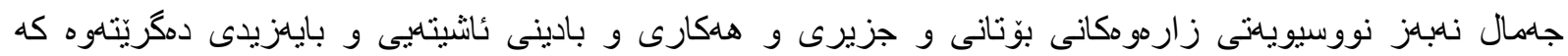

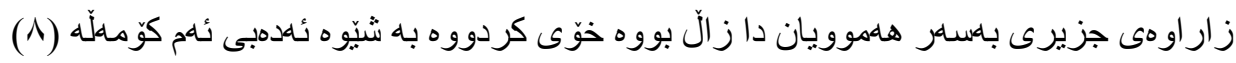

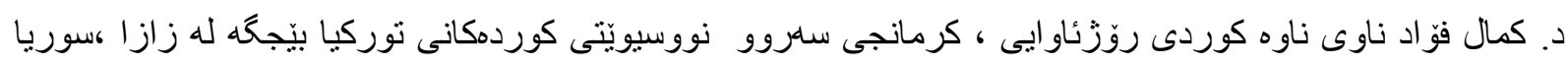

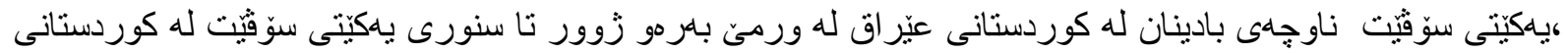

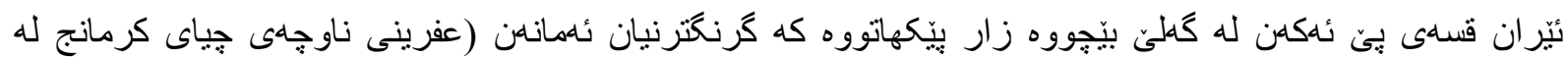

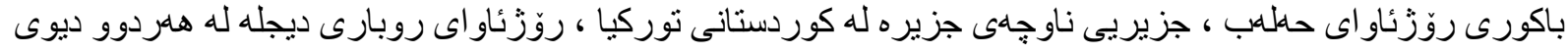

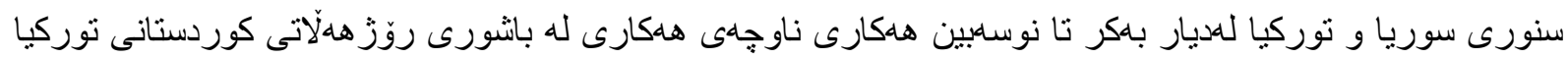

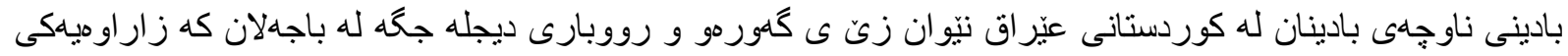

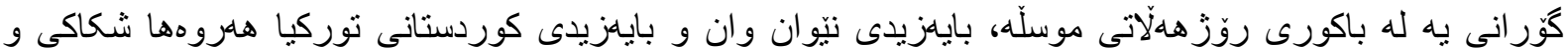

(9) سنجارى (9)

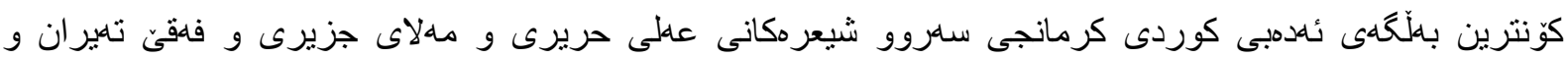

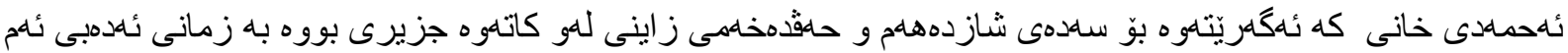
كوّمهلّه

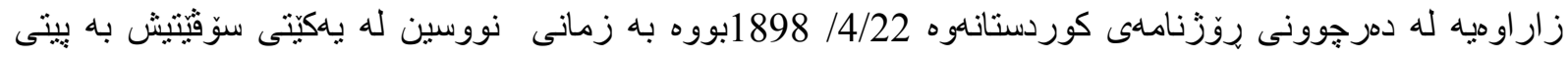

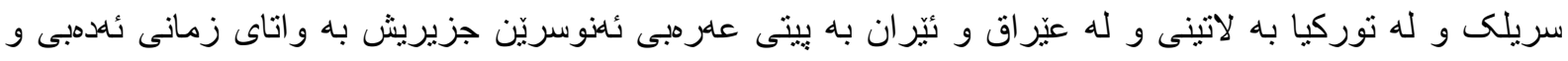

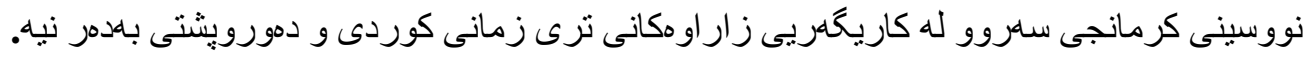




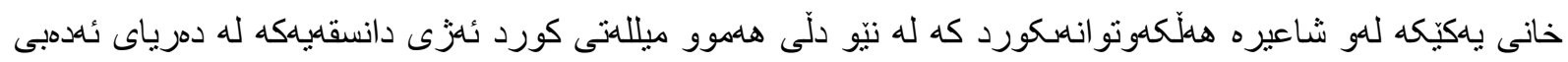

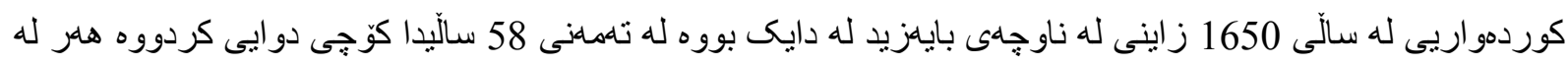

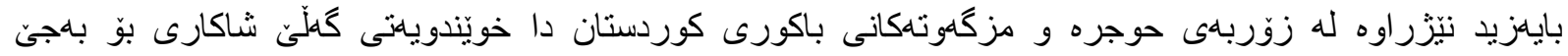

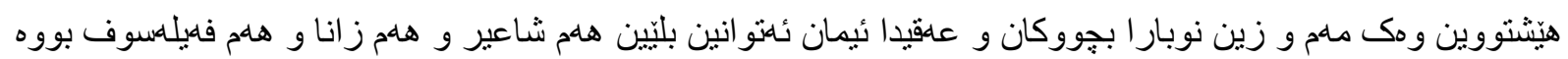

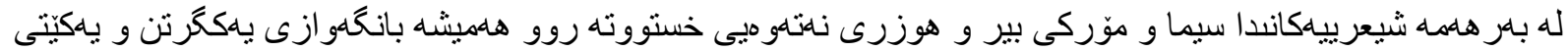

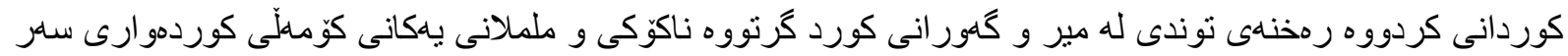

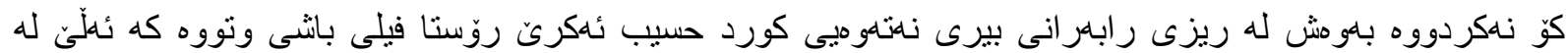

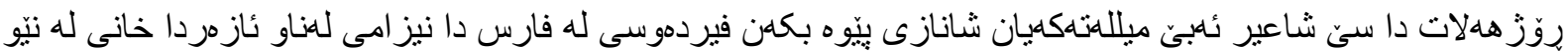

كوردان دا

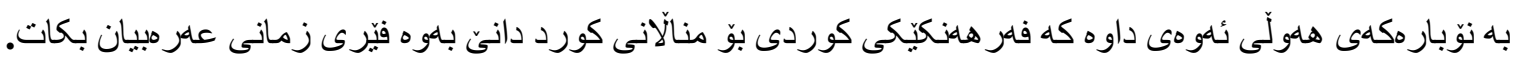

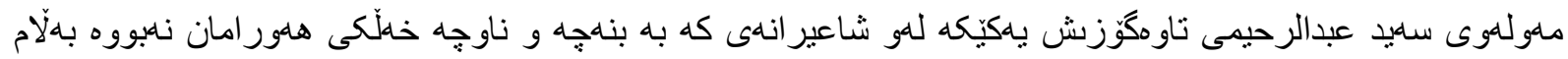

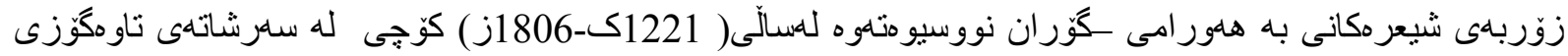

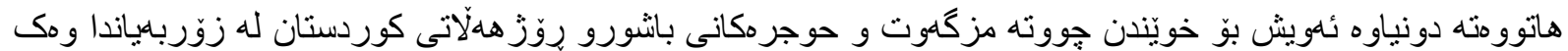

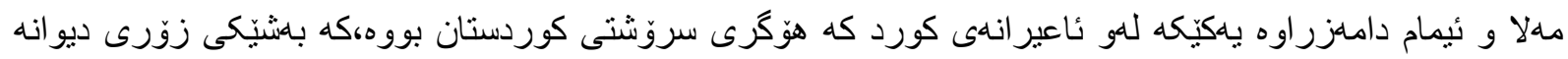

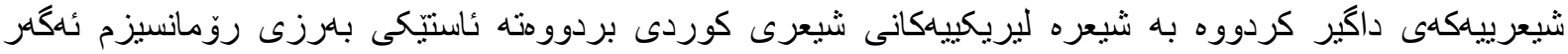

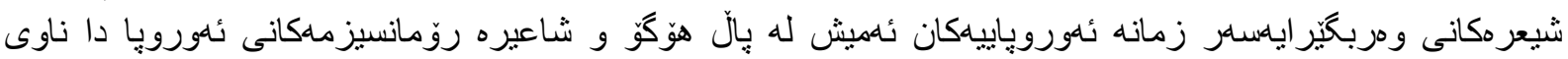

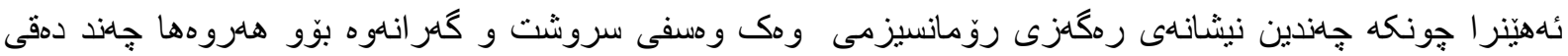

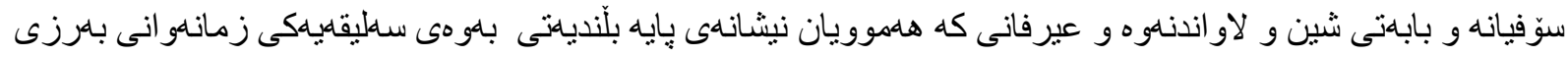

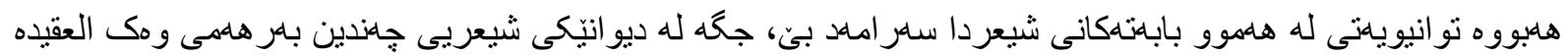

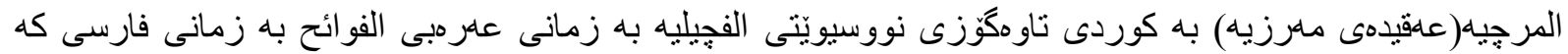

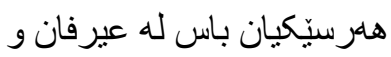

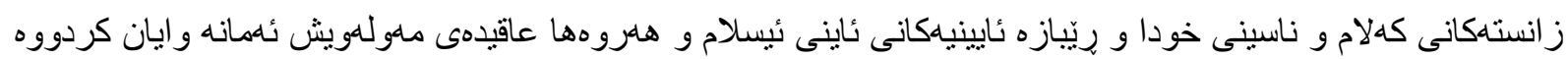

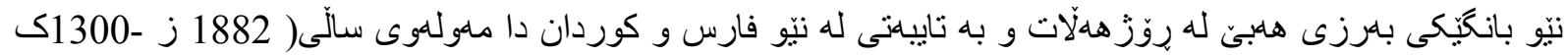

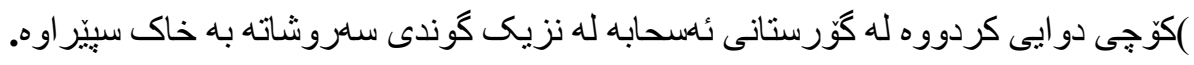

تاوهرى دووهم

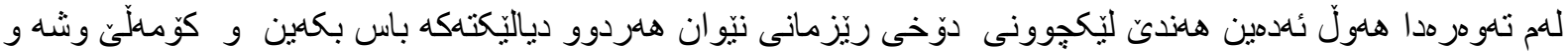

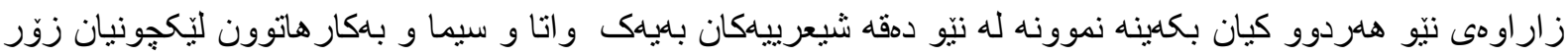

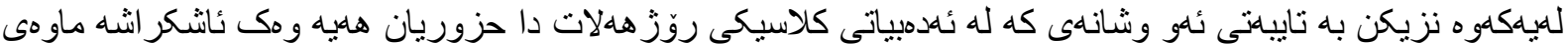

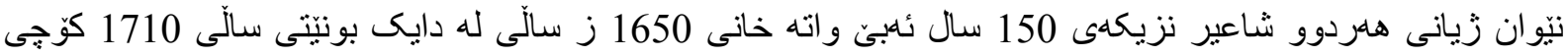

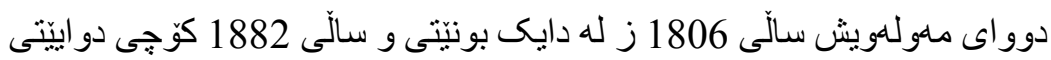

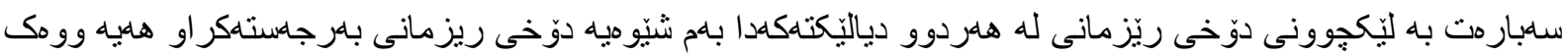

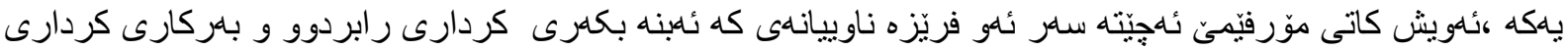

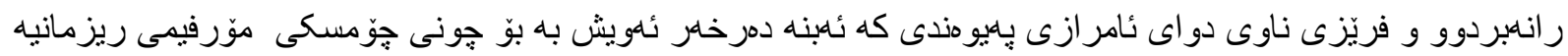

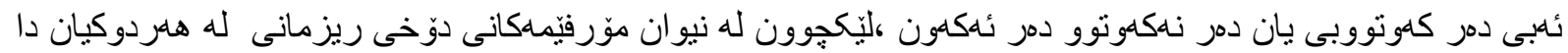

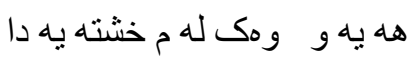

$$
\text { كرمانجى }
$$

هاهور امىى

$\checkmark$ تاكى نيّز 


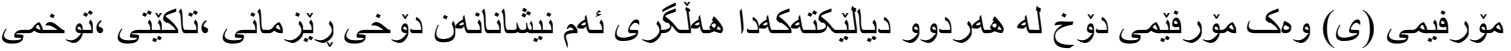

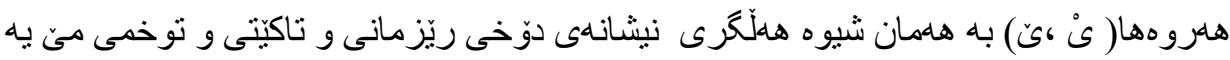

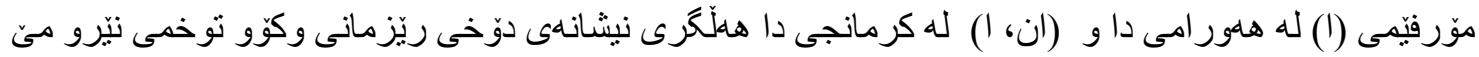

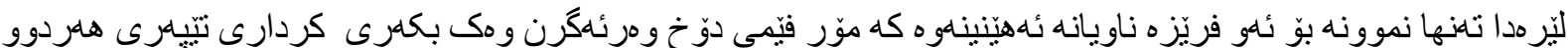

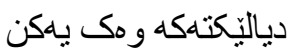
بكمرى كردارى تنبيهر له هدردوو دياليكتهكه(*) نموونه

هاdور امى

كرمانجى

هلور امى

كرمانجى

هلور امى

كرمانجى

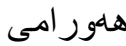

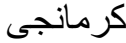

هيْمنى نانش و ارد

هيْمنى نان خوار

شليّرىن نانش وارد

شليّريّ نان خوار

ئا كوري نانشا وارد

بوّ نبّرى كوّ

ئدوان كورير نان خوارن

ئا كناجا نانشاو ارد

بوّ مي كوّ

ئلهوان كجا نان خوارن

ئهم زانياريه له به، فهريدون عهبدول محمد وه وهركير اوه له نويّزينهو هيهكى ئامادمكر او و بلاو نهكر اوهدا

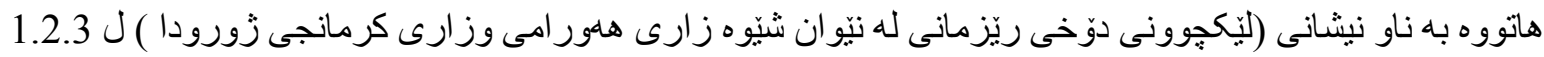

$$
\begin{aligned}
& \text { ئماهش كهر هساهو نموونهى ئهو وشانهن كه لاى هلردووكيان وهك يهك و اتاو سيما هاتوون. }
\end{aligned}
$$

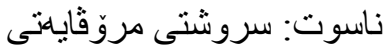

$$
\begin{aligned}
& \text { ئشياح مور مسسامن ز ناسوت }
\end{aligned}
$$

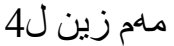

$$
\begin{aligned}
& \text { ئامرواح مو هسسه من به لاهوت . }
\end{aligned}
$$




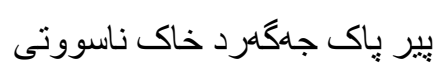

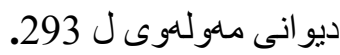

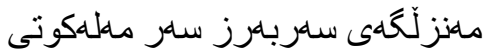

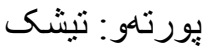

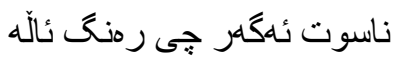

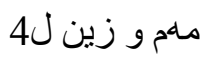
ل الاهوت ز يورته دا جامماله

$$
\text { كوم بى جوون خورشيد ئهو نهيرتهاودا }
$$

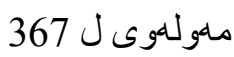

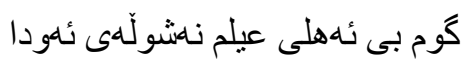

ليّهيقهل: مشت ومالّ كردن سيَ كردنهوه مهم وزين ل2

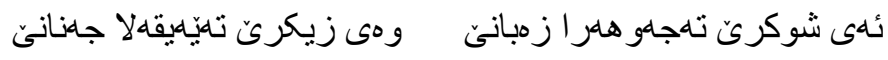

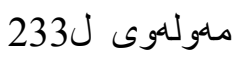

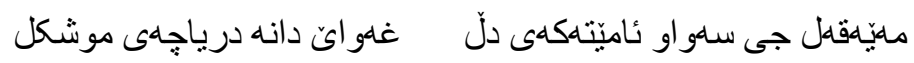

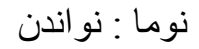

$$
\begin{aligned}
& \text { قاهيرته ئهكَر نومايه يَو غرا } \\
& \text { ماهم وزين ل } \\
& \text { بان ئموه نـخشيّ خامه كوبر ا } \\
& \text { سمروو بالاّيّى حوّرى نومايسي } \\
& \text { مالولهوى } 505 \\
& \text { خورشيد جلاييّ غيلمان ئاساييّ }
\end{aligned}
$$$$
\text { رشك: ائيرِ ميى داخ وخهفهت زيادكهر }
$$

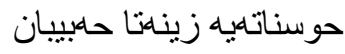

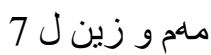
رهشكاتهيه غيره تار روقيبان خورشيد ساماى شيرين جامالان ماهو للهوى 189 رهشى ئدفز اى كروّى ديده غنز الان 


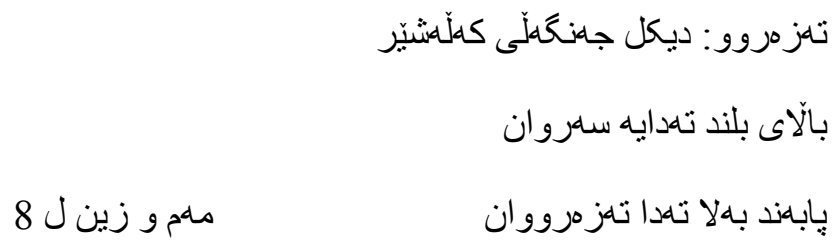

هلمسامر ب مهقامى سيدره ساروووهى

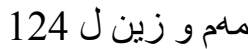
مانهندى فريشته هلم تهزمرووهك

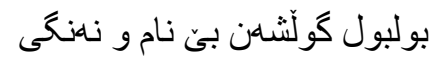
ماعولهوى ل 73

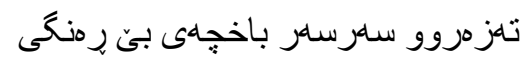
نهاو ا: خونيدنى ئاواز خو ش رمنحَى نهدا كَياى يْور كُول

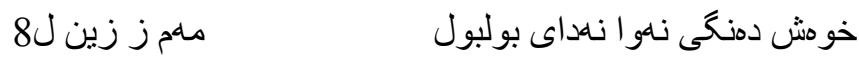

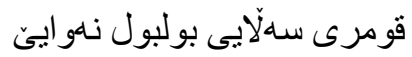
ماهو لهوى ل 506

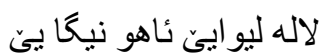

ئاينه: ئاوينينه ئاينه ته جيّ كرن مو كهريرمر خوسناخو دوان نهكر مويّاهوهر

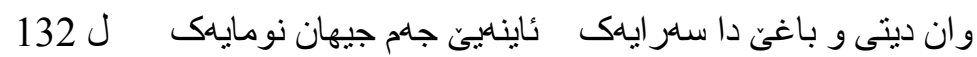
ئاينه كاملْ ئازيز هكهى فهرد ماول لهوى ل 47 فيداى ئامات بم بِهفاييت ئاو ردد 
تهشنه: تينوو

للهب تمشنه كَلهب دكن زهلالى

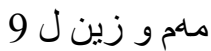

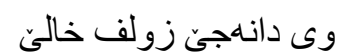

للمور اكو دو تهشنه للب دبيّ كاث

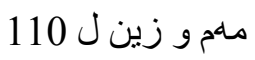

بيّ تاب بين ز بوّ فرهك ئاب

تهزننهى كييان وه للب ساوو داى سابوورى

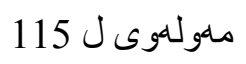

كهفته بيم نه كَيْج دهرياكهى دوورى

زيل و بام ، زير و بهام: دوو ئاميرى موسيقين سازيّ دلّى كول ب زيرو بهم بت

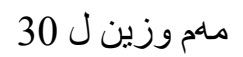
سازندهى عيشقيّ زين و مام بت

يّهداى زيل و بهام مدينهات بِّهو تهرزهن

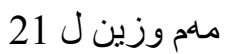
خهفهت شاديشان خهم دمماخ بارزمن

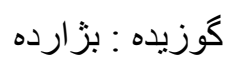
ئهو بار ميه كيفله نهو رهسيده

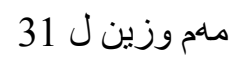
هامرجهندى نهن قهوى گوزيده وش ثئاماى رمخهير هلى باركوزيده

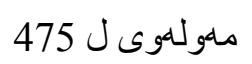
بوّ نهجاى مدردوم جاكَرنه ديده

ماه تاماهى:مانگ هلتا ماسى ئإِاريّ شهاعهنا وى شـاهى

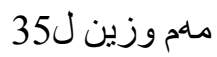
داكرت ز ما تا ماهى 


$$
\begin{aligned}
& \text { باعب و جود جاما تا ماهى } \\
& \text { دهليل إيبات ينّع ئيلاهى مدولهوى ل60 }
\end{aligned}
$$

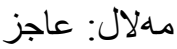

$$
\begin{aligned}
& \text { حور ان كره ماسكانيّ خوه جانناته } \\
& \text { مام وزين ل } \\
& \text { بيّ يهرده و بيّ ملهلال و ميننهت } \\
& \text { شاهيد داناى كردين ئهحو الاّن }
\end{aligned}
$$

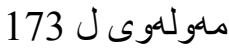

$$
\begin{aligned}
& \text { و وساهن بِّى راسى علرزهى مهلالان } \\
& \text { مانم و زين ل } \\
& \text { كيسوو: بارجهام } \\
& \text { كاكوّل كربوونهكَّره همرسو } \\
& \text { يُهرجهام كربوونه زولف و كيسوو }
\end{aligned}
$$

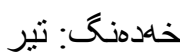

$$
\begin{aligned}
& \text { وان كو بثير و شُش بِارن ئهو }
\end{aligned}
$$

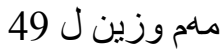

$$
\begin{aligned}
& \text { يا نه ب خهدهنى و خهنجارن ئادو } \\
& \text { ياكمر ده بوّ دلّ ديّو انهى دلّ تهنح }
\end{aligned}
$$

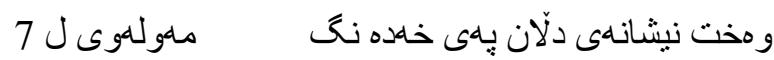

$$
\begin{aligned}
& \text { دلفگار : شاككهت ، كرفتار } \\
& \text { يانه وههه ئهم جر إنكارين؟ } \\
& \text { ماهم و زين ل } \\
& \text { مهجروح و جهعيف و دل فكارين }
\end{aligned}
$$




\begin{tabular}{|c|c|}
\hline \multirow[b]{2}{*}{ معالهوى ل 27} & كهرهم دمر نهدهس رجاى نُلهو كار ان \\
\hline & بو باهشَهم وه عهشق مزنهى يار ان \\
\hline \multirow[b]{3}{*}{ ماهم و زين خانى ل 53} & 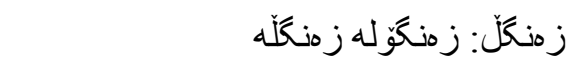 \\
\hline & 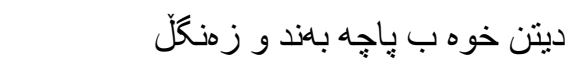 \\
\hline & يهارواز و فرين محال و موشكيل \\
\hline \multirow{4}{*}{ 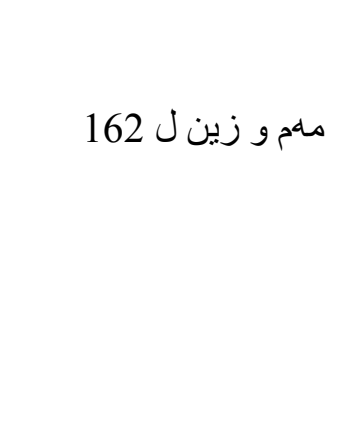 } & ويَناهى عوقدهى يِّج ريشـاى ئسروا و دلّ \\
\hline & سسته بوّ جام نم خووى موّبهت زهنكلّ \\
\hline & يهرواز: فرين هلمان ديّرى خانى ل 53 \\
\hline & لمهم جون شابازى ويّلّ شكار بوّ \\
\hline \multirow[t]{3}{*}{ 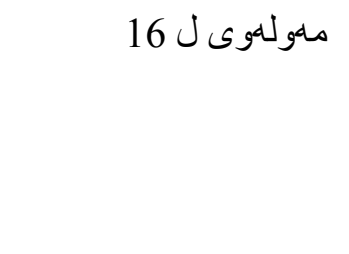 } & دايم بالّ پِرواز نهساكر ديارى بوّ \\
\hline & كين : موّرخانهى ئهموستيله \\
\hline & يومنا يجهمنيّد و ان نكينان \\
\hline \multirow[t]{2}{*}{ مام و زينى خانى ل 54} & بت ب و قوفي دوور بينان \\
\hline & لرخ هلر تئهو جهارخان تائاوهرد و بارد \\
\hline \multirow[t]{3}{*}{ ماهو للهوى ل 178} & دهس ئاو دهس نكين تاخاتهم ئاو هرد \\
\hline & يَّ: فيدا، خوّبهخت كردن \\
\hline & افقت ز وهر ا مهكَر خوديّ بت \\
\hline مهم و زين خانى ل 57 & انى مهدز بوّ ومر ا فديَّ بت \\
\hline
\end{tabular}

جهرسامر قهلاوه مهكَّلّوون بهاى توّ 
نيهال: نهمام نهو نهمام نهمامى باغ كِّى هلهز مكار (بارجهلّه) سار كَهله غهز الىي دمست و دموران

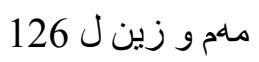
سار كَشته نيهالى باغو و وهردان ساماى دمسمالّان رمماى نهو هالاّن

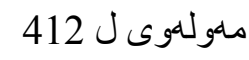
نهماى مهلالان نماى وهش حالان 


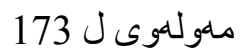

جاهو ر اسه باز اري شار مكهى ئلطلس

كهنج: كهنج رمو و خوار

رونه تول تهختى شبهيّ خوسر ور

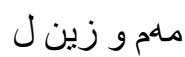

تاجيّ خوه بيّ زيّر بكيره كه تج رمو

جار نيان جادهس جليوه نـكهردهن

ماعو لكوى ل 32

بسماله ئمو تيخ ئيّد كه جهى كَردمن

بيّ توّ باهو خشو ع دمس وه دو عاوه

ماهولنوى ل 95

كيّ كَردمن كه جَ بوّ نهو بارهكاوه

جان فز ا: كيان زيدهكره روح ندفزا

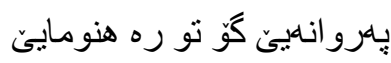

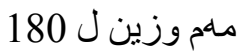
شَمعى وهه كُو توجان خز ايَ

نامهى روح ئدفز اى شيرينت ياوا

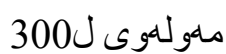
دلّ وه مهرد و مهك دوو ديدمش ساو ا

و ولوهله: هلراو هاو ار خهمبارى دنكى دهف

بوو وملوهله و فيغان و زارى

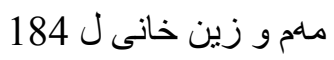

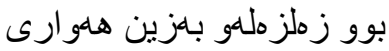

ياو ملولهى دهف شا دهرويَش جوَشيّ باهو يَّلهاى ريشاهى دلّ ئاشناوه يا جوَش سهمنور مكرب خروّشَّ

ماعولهوى ل جهني ئلى دوو فهرد حهسرهت مهعناوه 


$$
\begin{aligned}
& \text { باوهر نهكوّرهى و ولو ملهى دمف دا } \\
& \text { مالمولهوى ل } \\
& \text { روو يهند و تناوبيخ وههلر تمرهفدا } \\
& \text { شاخ ،شاخه :لق و يوّوبٍ } \\
& \text { بادام سياه و جهشمى شههلا } \\
& \text { مدم وزين خانى ل } 190 \\
& \text { نار بيهو سيّق و شاخَّ بالَا } \\
& \text { كوشو اه: كواره } \\
& \text { مهحبوبه ليباس و كوشواره }
\end{aligned}
$$

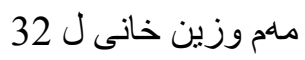

$$
\begin{aligned}
& \text { ملكيّ د منن ناموستهعاره } \\
& \text { ج شيرين زمركمر توّف هلو اى سامرد }
\end{aligned}
$$
نيجير: راوى كيانهوهرى ر او كر او،ر اوكردن راباستى سيلاح و كورز و شمشيّر

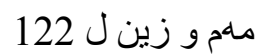
بيلجومله د كَل مه بيّنه نيّجير

$$
\text { من نه جيرهكهى ههز ار زام وهرده }
$$

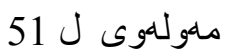
هلر ز امئ بِاهى ويّش زورخاوسامركمرده 


$$
\text { كئل }
$$




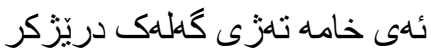

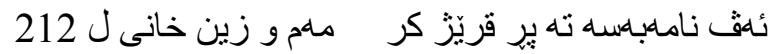
يادا يِّم نامهى شيرين خيتامهت

ئهمهش هلندي لهو وشاهو زار او انهى كه له بِيّشدا ئاماز هم بوّ كردن

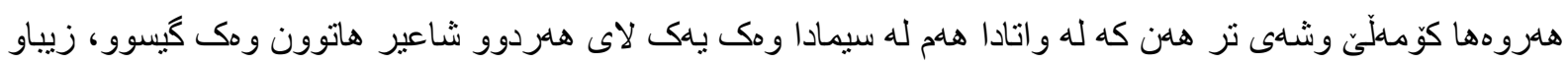

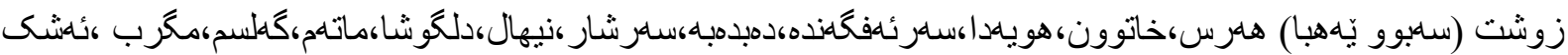

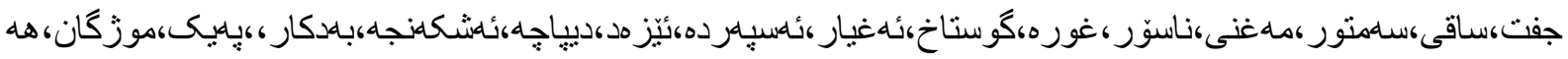

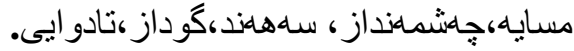
ومك ماهو للهوى ئسفهرميّ

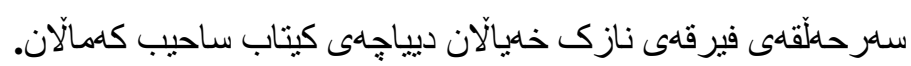

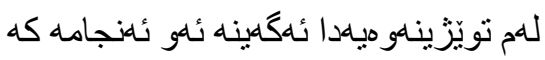

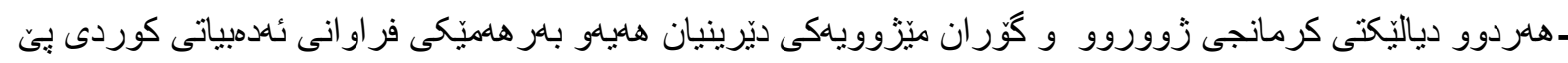

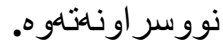

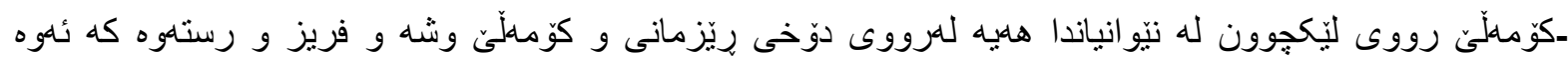

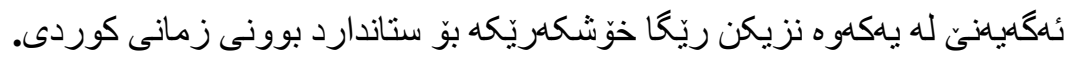

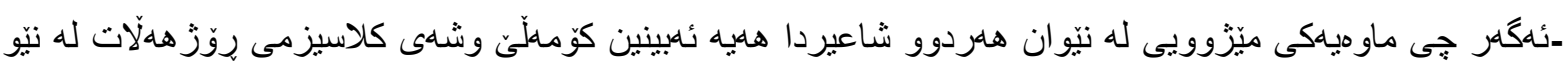

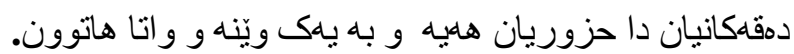

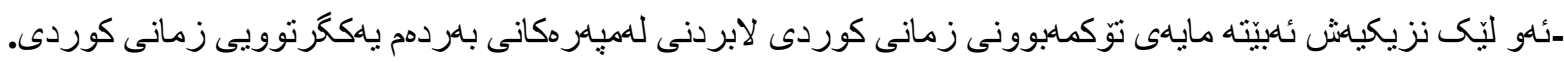

\section{سلرجاو وكان}

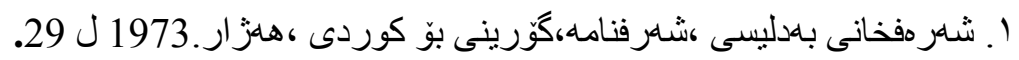

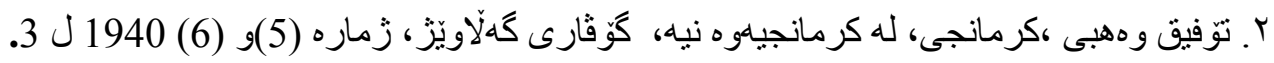

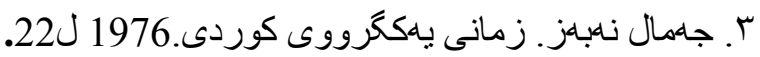
ع. مانثاء الله سورى ،سرودهاى دينى،ياريسان ل19. 


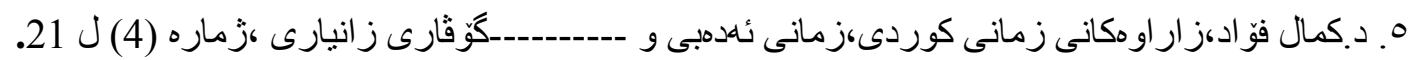

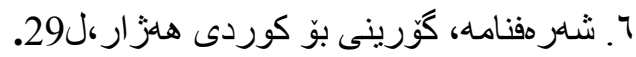

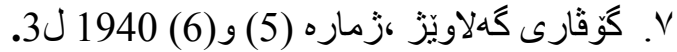

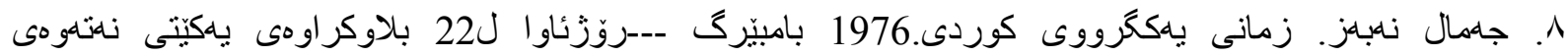
خويَندكار انى كورد له نئموروبيا.

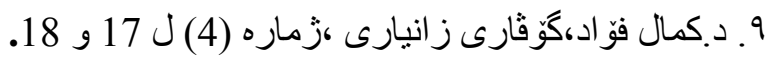

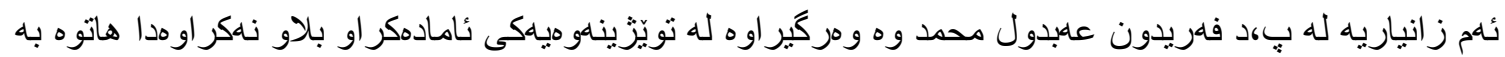

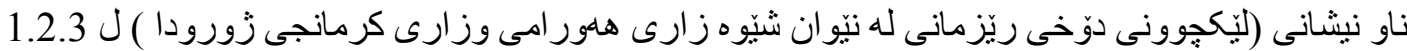

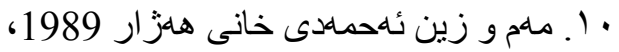

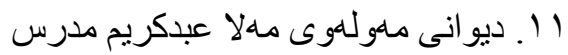

